\title{
Bronchodilator and Cardiac Effects of Isoprenaline, Orciprenaline, and Salbutamol Aerosols in Asthma
}

\author{
A. D. MILNER and D. INGRAM \\ From The Hospital for Sick Children, Great Ormond Street, London
}

\begin{abstract}
Milner, A. D., and Ingram, D. (1971). Archives of Diseases in Childhood, 46, 502. Bronchodilator and cardiac effects of isoprenaline, orciprenaline, and salbutamol aerosols in asthma. The bronchodilator and cardiac effects of $0.5 \%$ isoprenaline, $2.5 \%$ orciprenaline, and $0.5 \%$ salbutamol, and a placebo solution inhaled as a nebulized mist from a Wright nebulizer were compared with the help of 12 asthmatic children. All three active drugs produced similar relief of bronchoconstriction, but salbutamol was followed by only a $13 \%$ increase in heart rate compared with $26 \%$ after orciprenaline and $29 \%$ after isoprenaline, and only a $9 \%$ increase in systolic blood pressure compared to $13 \%$ after orciprenaline and $15 \%$ after isoprenaline.
\end{abstract}

For many years nebulized isoprenaline solutions have proved useful in the treatment of asthmatic children admitted with severe bronchoconstriction. Their use gives the child some relief from his symptoms but almost always is accompanied by tachycardia, and may actually cause a fall in arterial $\mathrm{Po}_{2}$ by augmenting ventilation/perfusion mismatch (Palmer and Diament, 1967).

Three bronchodilators-isoprenaline, orciprenaline, and salbutamol-were investigated to see which produced most relief of bronchospasm with least cardiac disturbance.

\section{Subjects}

The 12 children ( 6 boys and 6 girls) all attended the asthma clinic of The Hospital for Sick Children. Their ages ranged from 10 years 6 months to 14 years 4 months, with a mean of 11 years 9.5 months. All the children had had symptoms of asthma for over 7 years, and 10 had been on steroids for at least 6 months at some time. At the time of the trial 3 were on steroids and 11 were on disodium cromoglycate, with or without isoprenaline (Intal co. and Intal). Six of the children were below the 3rd centile for height.

\section{Procedure}

Each child attended on four occasions. The visits tended to be at irregular intervals but each child was kept to a morning or afternoon session to reduce errors from fluctuations in airways resistance during the day (Lewinsohn, Capel, and Smart, 1960). The parent was

Received 18 January 1971. asked not to give the child any bronchodilator or isoprenaline on the day of the test but steroids were not discontinued.

On arrival, lung function was assessed from measurements of the forced vital capacity (FVC) and the forced expiratory volume over $0.75 \mathrm{sec}\left(\mathrm{FEV}_{0.75}\right)$ using a reverse plethysmograph. The $\mathrm{FEV}_{0 \cdot 75}$ was measured rather than the $\mathrm{FEV}_{1.0}$ because some young healthy children are able to breathe out their FVC in 1 second (Lunn, 1965). The reverse plethysmograph consists of a rigid container, volume 1,500 litre (Fig. 1). The

REVERSE PLETHYSMOGRAPH SYSTEM

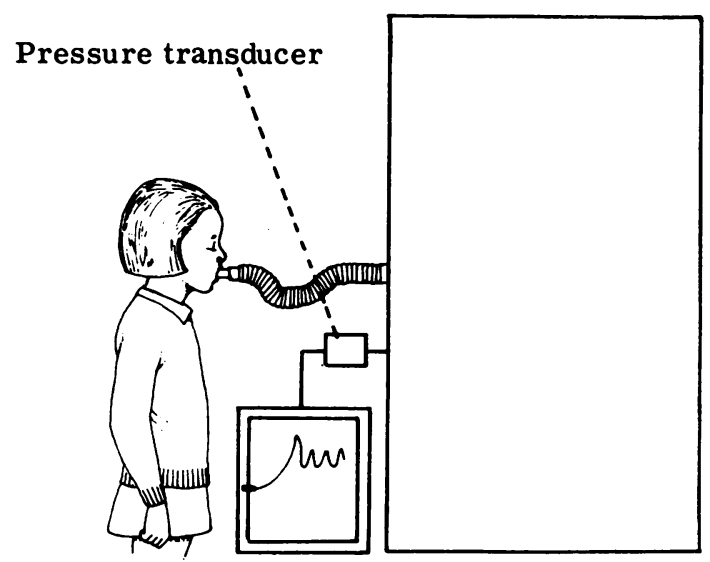

FIG. 1.-The reverse plethysmograph. 


\section{Bronchodilator and Cardiac Effects of Isoprenaline, Orciprenaline, and Salbutamol Aerosols 503}

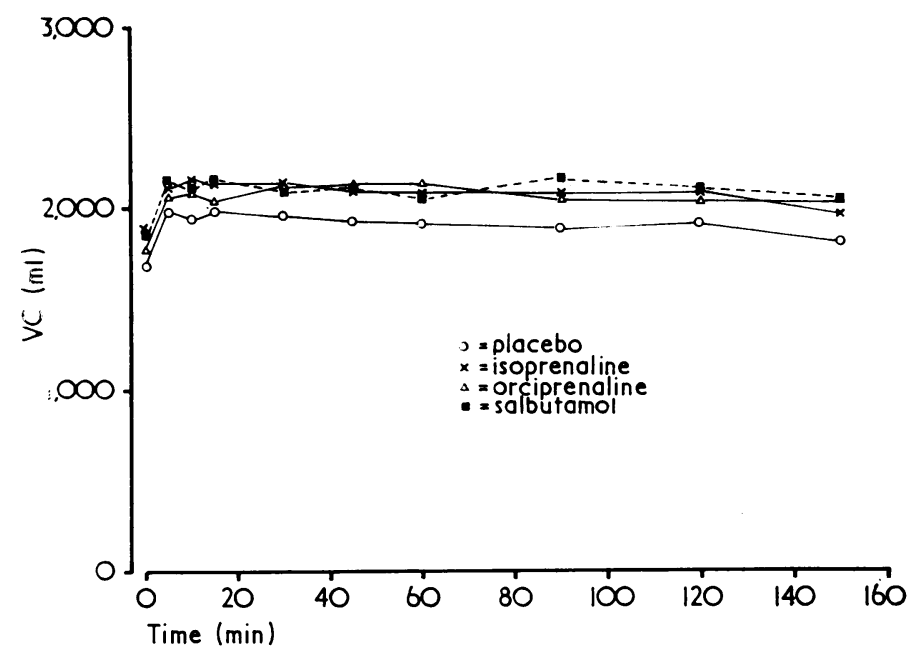

FIG. 2.-Mean values for vital capacity before and after inhalation of isoprenaline, orciprenaline, salbutamol, and placebo.

child blows into the container which causes pressure changes in it of the order of $0.7 \mathrm{cmH}_{2} \mathrm{O}$ per litre of air expired. The changes are relayed to a fast hot wire Devices recorder by an Ether strain gauge transducer situated in the base of the tank. The system was calibrated against a $500 \mathrm{ml}$ syringe on each occasion. The advantage of this system over wet and dry spirometers is that it has no moving parts and is, therefore, not liable to errors from inertial drag and overswing. The system will detect $10 \mathrm{ml}$ volume changes and the standard error on repeated measurements of $500 \mathrm{ml}$ volumes delivered by a glass syringe was $1.68 \mathrm{ml}$. The best of three attempts was selected on each occasion and these results are expressed at ambient temperature and pressure. The pulse rate was measured using a Devices ECG preamplifier and recorder. The systolic and diastolic blood pressures were measured using a sphygmomanometer.

The child then breathed from a face mask connected to a Wright nebulizer containing $1.5 \mathrm{ml}$ active drug or placebo (distilled water). A compressed air cylinder provided a flow of $8 \mathrm{l} . / \mathrm{min}$ to the nebulizer. The child continued to breathe from this system until the nebulizer ceased to produce a mist, usually after 2 to 3 minutes. Initial experiments had shown that at this stage approximately $1 \mathrm{ml}$ solution had been nebulized, $0.5 \mathrm{ml}$ remaining on the walls of the nebulizer. Lung function tests, pulse and blood pressure measurements were repeated at $5,10,15,30,45,60,90,120$, and 150 minutes after administration of the mist.

\section{Statistical Analysis}

The measurements of lung and heart function that were made after taking each treatment were used to assess four characteristics of the response. These are as follows:

I Peak effect, i.e. maximum effect minus basal value.
II Time to peak, i.e. number of minutes after dosing at which peak occurred.

III Total effect, i.e. area under the response-time 'curve' above basal value.

IV Duration, i.e. duration of average effect.

Each of these aspects was examined by analysis of covariance to make allowance for the difference in basal value that were observed (Quenouille, 1953).

\section{Drugs}

The three bronchodilator drugs, $0.5 \%$ isoprenaline, $2.5 \%$ orciprenaline, and $0.5 \%$ salbutamol, and the placebo (distilled water) were prepared in individual vials and coded by random selection by Allen and Hanburys Ltd. Benzalkanonium chloride, 0.01\%, was added to all samples as a preservative. Each sample was identified by a number relating to the patient and a letter identifying the solution within. Thus, each child received each of the four solutions under doubleblind control conditions.

\section{Results}

Bronchodilator effect of drugs. The mean results of the improvement in $\mathrm{FVC}$ and the $\mathrm{FEV}_{\mathbf{0}} \cdot 75$ after inhalation of the three active drugs and placebo are shown in Figs. 2 and 3 . There was response to all solutions including the placebo. The peak effects of the three active solutions were very similar and only the difference in peak vital capacity between salbutamol and the placebo was statistically significant (Tables I and II). In 10 of the 12 children, the $\mathrm{FEV}_{0.75}$ rose by more than $25 \%$ from control levels after inhalation of the placebo. There was no significant difference in the rate of rise or the duration of effect over the 


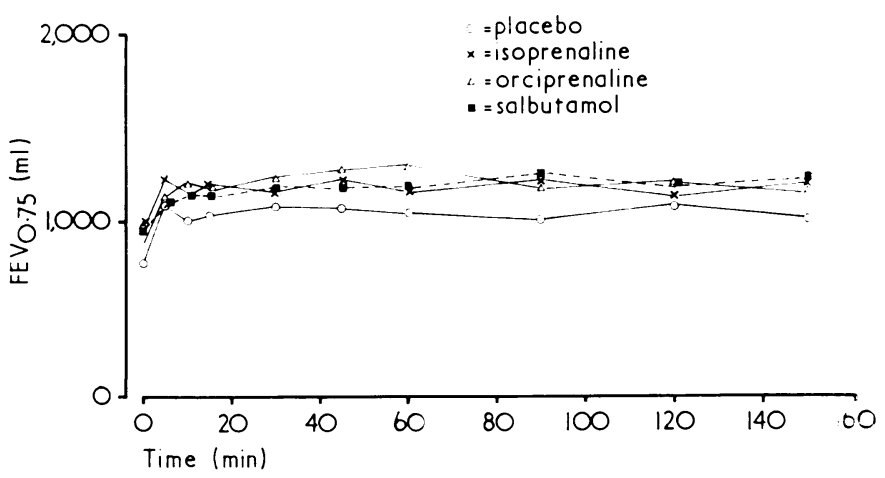

FIG. 3.-Mean values for $F E V_{0 \cdot i 5}$ before and after inhalation of isoprenaline, orciprenaline, salbutamol, and placebo.

TABLE I

Mean Changes in Forced Vital Capacity after Inhalation of Placebo, Isoprenaline, Orciprenaline, and Salbutamol

\begin{tabular}{l|c|c|c|cc}
\hline \multicolumn{1}{c|}{ Treatment } & $\begin{array}{c}\text { Basal } \\
\text { Value } \\
(\mathrm{ml})\end{array}$ & $\begin{array}{c}\text { Peak } \\
(\mathrm{ml})^{\star}\end{array}$ & $\begin{array}{c}\text { Time to } \\
\text { Peak } \\
(\mathrm{min})\end{array}$ & $\begin{array}{c}\text { Area } \\
(1 . \mathrm{min}){ }^{\star}\end{array}$ & $\begin{array}{c}\text { Dura- } \\
\text { tion } \\
(\mathrm{min}) \star\end{array}$ \\
\hline Placebo & 1683 & 305 & 44 & 26 & 79 \\
Isoprenaline & 1881 & 433 & 32 & 45 & 73 \\
Orciprenaline & 1771 & 453 & 54 & 45 & 85 \\
Salbutamol & 1837 & 464 & 57 & 50 & 73 \\
\hline Difference required for & & & & \\
significance (P=0.05) & 149 & 38 & 22 & 30 \\
\hline
\end{tabular}

^Significantly related to basal values, and adjusted accordingly.

period of the investigation as judged by the FVC, but the total effect of salbutamol, as measured by integration of the area under the curve, was significantly larger than the placebo.

2. Cardiac effects of drugs. All four solutions were followed by an increase in the pulse rate
TABLE II

Mean Changes in FEV 0.75 after Inhalation of Placebo, Isoprenaline, Orciprenaline, and Salbutamol

\begin{tabular}{l|c|c|c|c|c}
\hline Treatment & $\begin{array}{c}\text { Basal } \\
\text { Value } \\
(\mathrm{ml})\end{array}$ & $\begin{array}{c}\text { Peak } \\
(\mathrm{ml})^{\star}\end{array}$ & $\begin{array}{c}\text { Time of } \\
\text { Peak } \\
(\mathrm{min})\end{array}$ & $\begin{array}{c}\text { Area } \\
(\text { l. min })\end{array}$ & $\begin{array}{c}\text { Dura- } \\
\text { tion } \\
(\mathrm{min})\end{array}$ \\
\hline Placebo & 773 & 349 & 53 & 31 & 84 \\
Isoprenaline & 997 & 463 & 59 & 41 & 76 \\
Orciprenaline & 822 & 536 & 63 & 53 & 96 \\
Salbutamol & 968 & 446 & 68 & 48 & 84 \\
\hline Difference required for & & & & 22 & 25 \\
significance (P=0.05) & 186 & 36 & 22 \\
\hline
\end{tabular}

*Significantly related to basal value, and adjusted to allow for variation among the four mean basal values.

(Fig. 4). This was very small after the placebo $(+3 \%)$ and relatively small after salbutamol $(+13 \%)$ but was significantly larger after isoprenaline $(+29 \%)$ than after salbutamol and placebo, and significantly larger after orciprenaline $(+26 \%)$ than after the placebo (Table III). The tachycardia after salbutamol lasted significantly

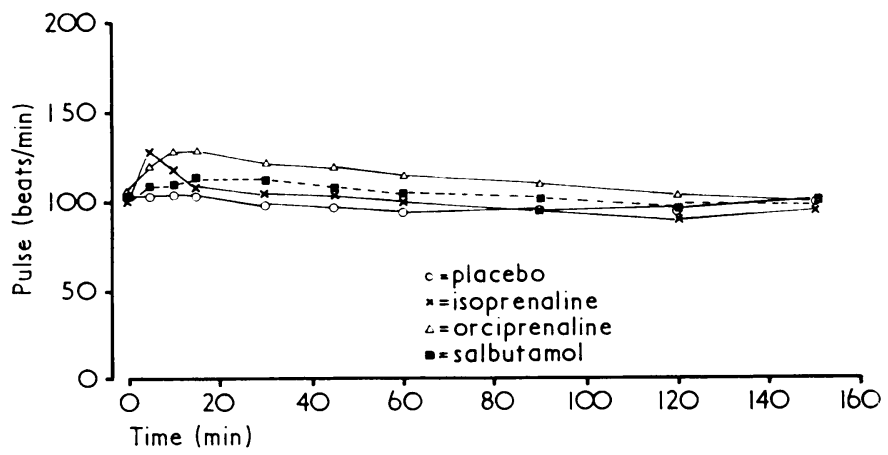

FIG. 4.-Mean values for pu'se rate before and after inhalation of isoprenaline, orciprenaline, salbutamol, and placebo. 
Bronchodilator and Cardiac Effects of Isoprenaline, Orciprenaline, and Salbutamol Aerosols 505

TABLE III

Mean Changes in Pulse after Inhalation of Placebo, Isoprenaline, Orciprenaline, and Salbutamol

\begin{tabular}{l|c|c|c|cc}
\hline \multicolumn{1}{|c|}{ Treatment } & $\begin{array}{c}\text { Basal } \\
\text { Value } \\
\text { (beats/ } \\
\text { min) }\end{array}$ & $\begin{array}{c}\text { Peak } \\
\text { (beats/ } \\
\text { min) }\end{array}$ & $\begin{array}{c}\text { Time to } \\
\text { Peak } \\
\text { (min) }\end{array}$ & $\begin{array}{c}\text { Area } \\
\text { (beats/ } \\
\text { min) }\end{array}$ & $\begin{array}{c}\text { Dura- } \\
\text { tion } \\
\text { (min) }\end{array}$ \\
\hline Placebo & 104 & 10 & 36 & 520 & 22 \\
Isoprenaline & 100 & 32 & 11 & 743 & 25 \\
$\begin{array}{l}\text { Orciprenaline } \\
\text { Salbutamol }\end{array}$ & 107 & 28 & 20 & 1427 & 42 \\
\hline $\begin{array}{l}\text { Difference required for } \\
\text { significance (P =0.05) }\end{array}$ & 11 & 20 & 908 & 45 \\
\hline
\end{tabular}

longer than after isoprenaline. Orciprenaline had the largest effect on the heart rate as judged by the 'area under the curve', but this only reached significance when compared to placebo (Table III).

Only the placebo solution produced no rise in systolic blood pressure (Fig. 5) but the effect of salbutamol was slight. Isoprenaline and orciprenaline were both followed by significant increases compared to the placebo solution (Table IV and V). Orciprenaline again had the largest total effect.

As regards diastolic pressure, only isoprenaline had an appreciable effect, causing a $13 \%$ increase.

Order of drug administration. The results were also examined to see whether there was any difference in the cardiovascular and bronchodilator response between the first and subsequent sessions, as it was felt that on the initial visit the
TABLE IV

Mean Changes in Systolic Blood Pressure after Inhalation of Placebo, Isoprenaline, Orciprenaline, and Salbutamol

\begin{tabular}{l|c|c|c|c|c}
\hline \multicolumn{1}{|c|}{ Treatment } & $\begin{array}{c}\text { Basal } \\
\text { Value } \\
(\mathrm{mmHg})\end{array}$ & $\begin{array}{c}\text { Peak } \\
(\mathrm{mmHg})\end{array}$ & $\begin{array}{c}\text { Time to } \\
\text { Peak } \\
(\mathrm{min})\end{array}$ & $\begin{array}{c}\text { Area } \\
(\mathrm{mm} . \mathrm{min})^{\star}\end{array}$ & $\begin{array}{c}\text { Dura- } \\
\text { tion } \\
(\mathrm{min})^{\star}\end{array}$ \\
\hline Placebo & 99 & 4 & 28 & 168 & 19 \\
Isoprenaline & 101 & 15 & 5 & 500 & 25 \\
Orciprenaline & 98 & 13 & 10 & 555 & 37 \\
Salbutamol & 97 & 9 & 29 & 409 & 41 \\
\hline Difference required for & & 30 & 327 & 19 \\
\hline
\end{tabular}

«Significantly related to basal value, and adjusted accordingly.

TABLE V

Mean Changes in Diastolic Blood Pressure after Inhalation of Placebo, Isoprenaline, Orciprenaline, and Salbutamol

\begin{tabular}{l|c|c|c|cc}
\hline \multicolumn{1}{|c|}{ Treatment } & $\begin{array}{c}\text { Basal } \\
\text { Value } \\
(\mathrm{mmHg})\end{array}$ & $\begin{array}{c}\text { Peak } \\
(\mathrm{mmHg})^{\star}\end{array}$ & $\begin{array}{c}\text { Time to } \\
\text { Peak } \\
(\mathrm{min})\end{array}$ & $\begin{array}{c}\text { Area } \\
(\mathrm{mm} . \mathrm{min})^{\star}\end{array}$ & $\begin{array}{c}\text { Dura- } \\
\text { tion } \\
(\mathrm{min})^{\star}\end{array}$ \\
\hline Placebo & 61 & 3 & 2 & 88 & 11 \\
Isoprenaline & 60 & 7 & 18 & 257 & 27 \\
Orciprenaline & 63 & 3 & 26 & 94 & 22 \\
Salbutamol & 60 & 3 & 10 & 214 & 28 \\
\hline Difference required for & & & & 19 \\
\hline significance (P=0.05) & 3 & 24 & 157 & 19 \\
\hline
\end{tabular}

^Significantly related to basal value, and adjusted accordingly.

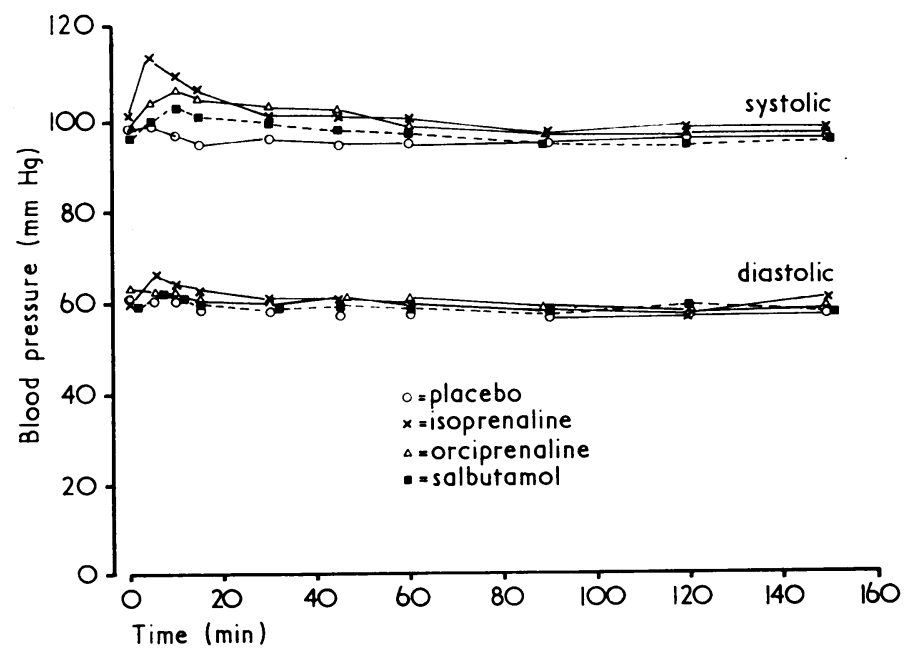

FIG. 5.-Mean values for systolic and diastolic blood pressure before and after inhalation of isoprenaline, orciprenaline, salbutamol, and placebo. 
children might be more anxious and less able to achieve their best results. Analysis showed that the improvement in forced vital capacity as judged by its total effect was significantly less on the first than on subsequent occasions. No significant differences could be detected from examination of the pulse record.

Four children received salbutamol, 4 isoprenaline 3 placebo, and 1 orciprenaline on their first visit.

Side effects. Two children felt dizzy after isoprenaline and one felt dizzy after orciprenaline.

\section{Discussion}

One of the main problems in any trial designed to compare bronchodilator drugs is the dose selection. In this trial we selected doses which we hoped would be equipotent as regards relief of bronchoconstriction, so that we could then compare the cardiac effects. However, the information available on dose relation is contradictory. Some workers, e.g. Cullum et al. (1969) using cats and dogs, and Grant (1969), Choo-Kang, Simpson, and Grant (1969), Kamburoff and Prime (1970), and Riding, Dinda, and Chatterjee (1970), with normal and asthmatic adults, found that dose for dose salbutamol was several times more potent than isoprenaline. However, Warrell et al. (1970), using more sophisticated techniques, obtained very similar response curves for the two drugs, and Riding, Chatterjee, and Dinda (1969) found very similar relief of bronchoconstriction in asthmatic adults after the inhalation of $0.5 \%$ salbutamol and $0.5 \%$ isoprenaline delivered by an ultrasonic nebulizer. Hambleton and Shinebourne (1970) reported that $100 \mu \mathrm{g}$ doses of isoprenaline and salbutamol delivered as an aerosol produced very similar relief of airways obstruction in 10 children with asthma, but that the effect of salbutamol was more prolonged. When compared to salbutamol, orciprenaline was less effective in relieving bronchospasm even with six times the dose (Kennedy and Simpson, 1969), but it was not felt justified to exceed the relatively high concentration of $2 \cdot 5 \%$ in these children. Our results showed very similar improvements in $\mathrm{FEV}_{\mathbf{0 . 7 5}}$ and FVC after all three active drugs. However, they were less striking than in the other series, partly because these children have had severe asthma for many years and now have some permanent underlying lung damage. The response to placebo was striking, with 10 of the children showing an obvious improvement in $\mathrm{FEV}_{\mathbf{0}} \cdot \mathbf{7 5}$, again illustrating the need for good controls when assessing any treatment in asthma.
The cardiac effects of the drugs showed greater variation. As was expected, isoprenaline caused an increase in heart rate of up to $70 \%$; in only two children was the increase less than $20 \%$. The effect on the cardiovascular system was also reflected in the increase in systolic and diastolic pressure. Rather more surprising was the tachycardia and increase in systolic blood pressure associated with the orciprenaline. These changes persisted for longer than the changes after isoprenaline. Salbutamol did produce an increase in the heart rate which persisted for significantly longer than after isoprenaline, but the increase was much less marked than after the other two drugs. Riding et al. (1969) found a similar rise in the pulse rate after the inhalation of a nebulized solution of $0.5 \%$ in adults. However, Kennedy and Simpson (1969) found no change in pulse and blood pressure after the inhalation of $400 \mu \mathrm{g}$ salbutamol from an aerosol, and Riding et al. (1970) actually observed a fall after $200 \mu \mathrm{g}$.

It is possible that a similar degree of bronchodilatation could have been achieved with a considerably lower dose, but we were anxious to reproduce the doses likely to be given to a child admitted to the ward in severe bronchospasm. In conclusion, a $0.5 \%$ salbutamol solution delivered by a Wright nebulizer is as effective a bronchodilator agent as $0.5 \%$ isoprenaline or $2.5 \%$ orciprenaline, but had considerably less effect on the cardiovascular system and thus should be used in place of isoprenaline for children with severe bronchoconstriction.

We wish to thank Dr. A. P. Norman and Dr. D. Hull for their advice and encouragement, and Allen and Hanburys Ltd. who supplied the samples and carried out the statistical analysis. Financial support was provided by the Asthma Research Council.

\section{REFERENCES}

Capel, L. H., and Fletcher, E. C. (1964). Spirometric integrals after isoprenaline and atropine in asthma. British fournal of Diseases of the Chest, 58, 174.

Choo-Kang, Y. F. J., Simpson, W. T., and Grant, I. W. B. (1969). Controlled comparison of the bronchodilator effects of three $\beta$-adrenergic stimulant drugs administered by inhalation to patients with asthma. British Medical fournal, 2, 287.

Cullum, V. A., Farmer, J. B., Jack, D., and Levy, G. P. (1969). Salbutamol: a new, selective $\beta$-adrenoceptive receptor stimulant. British fournal of Pharmacology and Chemotherapy, 35, 141.

Grant, I. W. B. (1969). Bronchodilator aerosols. In New ideas in asthma and its management: Proceedings of the Chest and Heart Association Conference p. 48. Chest and Heart Association, London.

Hambleton, G., and Shinebourne, E. (1970). Evaluation of the effects of isoprenaline and salbutamol aerosols on airways obstruction and pulse rates of children with asthma. Archives of Disease in Childhood, 45, 766.

Kamburoff, P. L., and Prime, F. J. (1970). Oral and inhaled salbutamol as a bronchodilator. British fournal of Diseases of the Chest., 64, 46. 
Kennedy, M. C. S., and Simpson, W. T. (1969). Human pharmacological and clinical studies on salbutamol: a specific $\beta$ adrenergic bronchodilator. British fournal of Diseases of the Chest, 63, 165.

Lewinsohn, H. C., Capel, L. H., and Smart, J. (1960). Changes in forced expiratory volumes throughout the day. British Medical fournal, 1, 462.

Lunn, J. E. (1965). Respiratory measurements of 3556 Sheffield schoolchildren. British fournal of Preventive and Social Medicine, 19, 115.

Palmer, K. N. V., and Diament, M. L. (1967). Effect of aerosol isoprenaline on blood-gas tensions in severe bronchial asthma. Lancet, 2, 1232.

Quenouille, M. H. (1953). The Design and Analysis of Experiment, p. 9. Griffin, London.
Riding, W. D., Chatterjee, S. S., and Dinda, P. (1969). Clinical trial of a new $\beta$-adrenergic stimulant in asthma. British Fournal of Clinical Practice, 23, 217.

Riding, W. D., Dinda, P., and Chatteriee, S. S. (1970). The bronchodilator and cardiac effects of five pressure-packed aerosols in asthma. British Fournal of Diseases of the Chest,

64, 37. Warrell, D. A., Robertson, D. G., Newton-Howes, J., Conolly,
, M. E., Paterson, J. W., Beilin, L. J., and Dollery, C. T. (1970). Comparison of cardiorespiratory effects of isoprenaline and salbutamol in patients with bronchial asthma. British Medical fournal, 1, 65.

Correspondence to Dr. A. D. Milner, The Hospital for Sick Children, Great Ormond Street, London W.C.1. 